\title{
Correction to: Family reported outcomes, an unmet need in the management of a patient's disease: appraisal of the literature
}

\author{
R. Shah ${ }^{1 *}$ (D) F. M. Ali ${ }^{1}$ (D) A. Y. Finlay ${ }^{1}$ (I) and M. S. Salek ${ }^{2,3}$ (1)
}

\section{Correction to: Health Qual Life Outcomes (2021) 19:194 https://doi.org/10.1186/s12955-021-01819-4}

The original article [1] contained several typos which were mistakenly incorporated by the production team that handled this article.

All errors have since been corrected.

\section{Author details}

${ }^{1}$ Division of Infection and Immunity, School of Medicine, Cardiff University, Cardiff, UK. ${ }^{2}$ School of Life and Medical Sciences, University of Hertfordshire, Hatfield, UK. ${ }^{3}$ Institute of Medicines Development, Cardiff, UK.

Published online: 31 August 2021
Reference

1. Shah $\mathrm{R}$, et al. Family reported outcomes, an unmet need in the management of a patient's disease: appraisal of the literature. Health Qual Life Outcomes. 2021;19:194. https://doi.org/10.1186/s12955-021-01819-4.

\section{Publisher's Note}

Springer Nature remains neutral with regard to jurisdictional claims in published maps and institutional affiliations. original author(s) and the source, provide a link to the Creative Commons licence, and indicate if changes were made. The images or other third party material in this article are included in the article's Creative Commons licence, unless indicated otherwise in a credit line to the material. If material is not included in the article's Creative Commons licence and your intended use is not permitted by statutory regulation or exceeds the permitted use, you will need to obtain permission directly from the copyright holder. To view a copy of this licence, visit http://creativecommons.org/licenses/by/4.0/. The Creative Commons Public Domain Dedication waiver (http://creativecommons.org/publicdomain/zero/1.0/) applies to the data made available in this article, unless otherwise stated in a credit line to the data. 